\title{
INTEGRATION OF THE SLOVAK AND EUROPEAN WHEAT
} MARKET

\section{Artan QINETI}

Department of Economic Policy, Faculty of Economics and Management, Slovak University of Agriculture in Nitra, Slovakia

\section{Ema LAZORČÁKOVÁ}

Department of Economic Policy, Faculty of Economics and Management, Slovak

University of Agriculture in Nitra, Slovakia

Received: 18. November 2020, Reviewed: 23. December 2020, Accepted: 30. December 2020

\begin{abstract}
Slovak agricultural markets became a part of the European Union's markets in May 2004, when Slovakia joined the EU. The paper aims to analyse the integration of the Slovak and European agricultural market in the case of the most important cereal crop - wheat. It studies two dimensions of market integration: foreign trade and price relations. The results show that EU countries are the most important trade partners for Slovakia with exports to the EU achieving up to $61 \%$ of domestic wheat production. The same pattern in the development of Slovak and EU (French) wheat prices has been revealed what indicates the cointegration of the Slovak and European wheat market.
\end{abstract}

Key words: wheat market, wheat trade, price cointegration, Slovakia, European Union (EU)

JEL Classification: Q02, F14, C22

\section{Introduction}

Agriculture can be considered the first economic sector that has developed in the human society. It is crucial to satisfy primary human needs and to provide nutrition for the population, but it also serves other economic, social and environmental functions (Van Huylenbroeck et al., 2007). Growing cross-national cooperation in agricultural activities and in food production and the growing interdependence of world agricultural markets are referred to as globalisation. The process means global economic integration, rising trade and capital flows, internationalisation and standardisation of production and lower transaction costs (FAO, 2003). Slovak agricultural markets have been very tightly connected to the European markets since May 2004, when the country joined the European Union (EU). Slovakia became an integral part of the single EU market, what removed trade barriers and enabled free trade with other Member States. However, trade with third countries is regulated by EU trade policy, i.e. the import and export of agricultural commodities is subject to import tariffs and is controlled by licenses (NPPC, 2019; Braha et al., 2017). Moreover, the internal agricultural market of the EU is regulated by the Common Agricultural 
Policy of the EU (CAP). The CAP provides support to farmers with the aim to ensure a stable supply of affordable food, to facilitate farmers' income as well as to tackle climate change, to maintain rural areas, and to manage natural resources sustainably (EC, 2020; Tangermann - von Cramon-Taubadel, 2013; Tangermann, 2011). The CAP applies market measures to regulate and to stabilise the whole EU market in agricultural products. Market measures include for example public interventions by Member States' governments in order to mitigate price fluctuations and to balance demand and supply in sectors like wheat, barley, maize, rice, beef and veal, butter and skimmed milk powder (EC, 2020). For wheat, the intervention price was EUR 101.31 per tonne for up to 3 mil. tonnes (NPPC, 2019). The EC (2014) argues that new Member States (new EU Member States include: Czech Republic, Estonia, Cyprus, Latvia, Lithuania, Hungary, Malta, Poland, Slovakia, Slovenia) benefit from the CAP as access to CAP funding increased the income of agricultural companies, boosted modernisation and restructuring of the agricultural sector, led to a growth in agricultural trade and improved their competitiveness in the world market.

A significant part of total agricultural production (almost three quarters globally) serves to meet food demand (FAO, 2018). More than $50 \%$ of world daily caloric intake comes from cereal consumption (Awika, 2011). Global cereal production and consumption is dominated by three crops: wheat, maize, and rice (Shewry - Hey, 2015; Shewry et al., 2013; Abdulai, 2000; Amikuzuno et al., 2013). The European Union is one of the world's most important cereal producers (EC, 2019) and given the climate conditions in Europe, wheat is the most important cereal crop in the EU and in many of its Member States. For Slovakia, the dominant position of wheat in the structure of cereal production is very evident. Slovak data for 2018 show that wheat and spelt covered the area of 403.4 thousand ha, which is $54.3 \%$ of total area cultivated under cereals (743.2 th. ha), and production of wheat and spelt reached 1.9 mil. tonnes which means $47.7 \%$ of total cereal production (Eurostat, 2020).

This paper aims to analyse the integration of the Slovak and European agricultural market in the case of the most important cereal crop - wheat. We study integration facilitated by foreign trade and evaluate Slovak wheat exports and imports to/from the EU market. In addition, we also analyse development of Slovak and EU wheat prices. If both prices move in a similar pattern, the national and European wheat market are considered integrated.

\section{Material and Methods}

To evaluate the integration of the Slovak and European wheat market, we focus on two aspects: firstly, we analyse Slovak foreign trade in wheat and secondly, we analyse relationship of Slovak and European wheat prices in the period 2004-2018. We expect that international trade relations are getting more intensive and the share of Slovak exports and imports in total domestic production of wheat is getting larger. For prices we expect that the Slovak and European wheat market are cointegrated, that is, a long run relationship of Slovak and European prices is anticipated. To verify both hypotheses we use the following data and methods.

Eurostat data for annual wheat exports, imports and production in tonnes for the period 2004-2018 (15 observations) are utilised to analyse Slovak foreign trade in wheat and to calculate the share of export and import, respectively, in total Slovak production of wheat:

$$
\mathrm{S}_{(\mathrm{EX}, \mathrm{t})}=\mathrm{Q}_{(\mathrm{EX}, \mathrm{t})} \mathrm{Q}_{(\mathrm{S}, \mathrm{t})}
$$




$$
\mathrm{S}_{(\mathrm{IM}, \mathrm{t})}=\mathrm{Q}_{(\mathrm{IM}, \mathrm{t})} / \mathrm{Q}_{(\mathrm{S}, \mathrm{t})}
$$

where $\mathrm{S}_{(\mathrm{EX}, t)}$ is share of wheat export in total production of wheat in period $t, \mathrm{~s}_{(\mathrm{IM}, t)}$ is share of wheat import in total production of wheat in period $t, Q_{(\mathrm{EX}, t)}$ is quantity of exported wheat in period $t, Q_{(\mathrm{IM}, t)}$ is quantity of imported wheat in period $t$, $\mathrm{Q}_{(\mathrm{S}, t)}$ is wheat production in Slovakia in period $t$. Trade and production of all wheat in quantitative terms is considered.

EC data for monthly prices of wheat in the period 2004-2018 (from May 2004; 176 observations) are used to analyse the cointegration of Slovak and European wheat prices. Prices are represented by price indices with the average 2015 wheat price equalling 100.

Markets are cointegrated if there is a long run equilibrium relationship between the examined variables (Verbeek, 2004; Granger - Newbold, 1974). We run a cointegration regression on the European and Slovak wheat prices:

$$
\mathrm{P}_{(\mathrm{SK}, \mathrm{t})}=\mathrm{f}\left(\mathrm{P}_{(\mathrm{EU}, \mathrm{t})}\right)
$$

in the form:

$$
\mathrm{P}_{(\mathrm{SK}, \mathrm{t})}=\beta_{0}+\beta_{1} \mathrm{P}_{(\mathrm{EU}, \mathrm{t})}+\varepsilon_{\mathrm{t}}
$$

where $\mathrm{P}_{(\mathrm{SK}, t)}$ is Slovak wheat price in period $\mathrm{t}, \mathrm{P}_{(\mathrm{EU}, t)}$ is European wheat price in period $t, \beta_{0}$ and $\beta_{1}$ are coefficients, $\varepsilon_{t}$ is error term. Due to data availability, only prices of bread wheat are considered. European bread wheat price is proxied by French bread wheat price as France is the biggest wheat market in the EU. Prices in terms of price indices are considered.

To analyse the cointegration of markets, price time series of both regions must be stationary of the same degree. Therefore, we test stationarity of Slovak and EU wheat prices with a Dickey-Fuller test (H0: non-stationarity, presence of unit root) and a Kwiatkowski, Phillips, Schmidt, Shin test - KPSS test (H0: stationarity).

Consequently, we test residues from the cointegration regression with a Dickey-Fuller test for residues (H0: no cointegrating vector; residuals non-stationary) and a cointegrating regression Durbin-Watson test - CRDW test (H0: no cointegrating vector; residuals non-stationary) to confirm the cointegration of wheat markets and the existence of a long run equilibrium between Slovak and European wheat prices.

\section{Results and Discussion}

Gross agricultural production in Slovakia reached EUR 2,159.0 mil. in 2018. Crop production made up 57.3\% (EUR 1,236.4 mil.) of the total value of agricultural production. Cereals play an important role in the composition of crop production; they contributed EUR 575.6 mil. to the value of crop production $(46.6 \%)$. Produced wheat and spelt had the value of EUR 278.8 mil., which was almost a half $(48.4 \%)$ of total cereals output. In quantitative terms, Slovakia produced 1.9 mil. tonnes of wheat and spelt and 4.0 mil. tonnes of cereals together (wheat is $47.7 \%$ ).

Within the EU, the Slovak market is a rather small one. Gross agricultural production of the EU was EUR 420,448.4 mil. in 2018 (Slovak share was only 0.5\%), the value of crop output was EUR 227,209.4 mil. (Slovak share 0.5\%), the value of cereals production was EUR 48,804.3 mil. (Slovak share 1.2\%), and the value of wheat and spelt production was EUR 23,592.9 mil. (Slovak share 1.2\%). In 2018, total yield of 
cereals for the production of grain in the EU was 294.9 mil. tonnes (Slovak share 1.4\%), out of which wheat and spelt accounted for 137.9 mil. tonnes (Slovak share 1.4\%). (all data from: Eurostat, 2020).

\section{Wheat Production}

Wheat production in Slovakia from 2000 to 2018 was characterised by increasing yields per hectare and almost constant harvested area. The average hectare yield was 4.3 tonnes of wheat and the average area harvested was 378.0 th. ha. However, yields per hectare fluctuate significantly because of weather conditions. The highest wheat production could be observed in 2016, mainly due to higher yields per hectare. In 2018, wheat production reached 1.9 mil. tonnes. Compared to the best year, 2016, it is less by 0.5 mil tonnes and compared to the worst year, 2003, it is more by almost 1 mil. tonnes. (data source: SO SR, 2020). Wheat is mainly used by the milling and food industry to provide human nutrition, but it is also used as animal feed or for seeds (Jamborova, 2018; Matoskova et al. 2015).

Since 2000, the area under wheat in the whole EU-28 varied between 24.9 mil. ha (2003) and 27.2 mil. ha (2002). EU and EU-28 refer to 28 Member States although the number of EU members increased in the period 2000-2018 from 15 (Austria, Belgium, Denmark, Finland, France, Germany, Greece, Ireland, Italy, Luxembourg, The Netherlands, Portugal, Spain, Sweden and The United Kingdom) to 28 states (Cyprus, Czechia, Estonia, Hungary, Latvia, Lithuania, Malta, Poland, Slovakia, Slovenia joined the EU in May 2004, Bulgaria and Romania joined in January 2007, Croatia joined in July 2013). Yields per hectare show substantial differences among Member States. While the minimum hectare yield was only 0.5 tonnes of wheat per hectare (Cyprus, 2008), most productive countries often approach 10 tonnes per hectare (Ireland, Belgium). (data source: Eurostat, 2020). Total production of wheat in the whole EU reached on average 138.1 mil. tonnes with an annual variation of $+/$ $13 \%$ in the period from 2000 to 2018 . The most cultivated species is common wheat, more precisely common winter wheat and spelt. The biggest wheat producer in the EU is France. France delivers one quarter of wheat to the European market and together with Germany and the United Kingdom, the three countries produce $50 \%$ of EU wheat.

Graph 1: Wheat production in Slovakia and in the EU

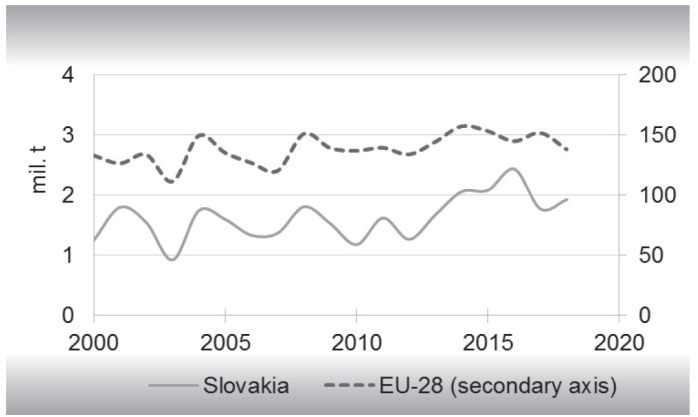

EU wheat producers (2018)

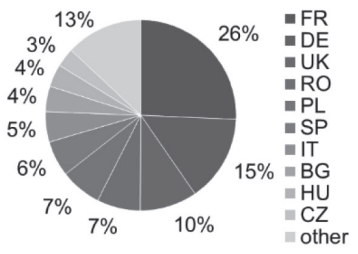

Data source: Eurostat (2020). 


\section{Wheat Trade}

Wheat production in Slovakia is sufficient to cover its domestic consumption (self-sufficiency index was 1.4 on average for the period 2002-2018). After Slovakia's accession to the EU, foreign trade with other Member States was simplified, and excess supply of wheat could be exported to other EU countries without any trade barriers. In 2002-2004 the average amount of wheat exported was 37.3 th. tonnes, while in 20052018 exports increased substantially to 590.2 th. tonnes on average. With the exception of 2004, 2005 and 2006, more than $95 \%$ of wheat exported from Slovakia was designated for other EU countries. Also, wheat imports increased, although at a lower rate than exports - from an average 9.1 th. tonnes in 2002-2004 to 54.0 th. tonnes in 2005-2018. Wheat is almost exclusively imported from other EU Member States, only in $20106.6 \%$ of imports originated in non-EU countries, and in 2008, 2013, 2014, 2016 imports from non-EU countries were recorded, however in quantities lower than $0.2 \%$ of total wheat imports.

In 2018, 37.3 mil. tonnes of wheat were imported by all EU Member States, thereof only $15.8 \%$ from third countries. Total EU exports of wheat reached 49.3 mil. tonnes with $39.2 \%$ designated for the markets of non-EU countries. (data source: Eurostat, 2020).

\section{Graph 2: Slovak foreign trade in wheat}

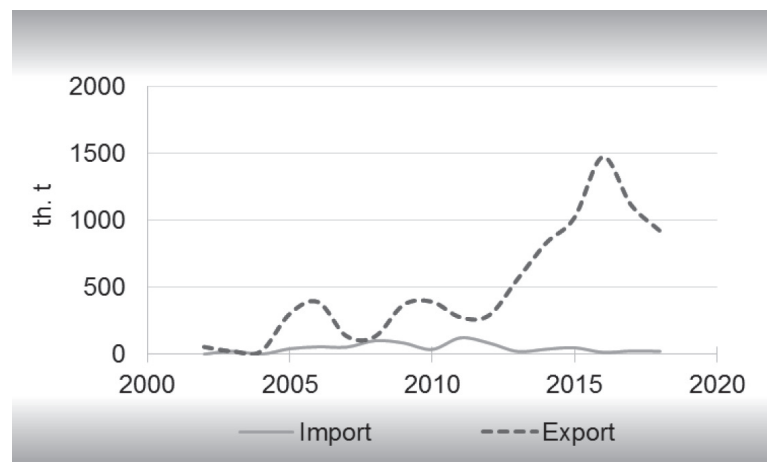

Data source: Eurostat (2020).

Slovak foreign trade in wheat has intensified since 2002. The total volume of wheat imports and exports was 61.2 th. tonnes in 2002 and it increased to 949.7 th. tonnes in 2018. The maximum quantity of wheat traded was 1492.6 th. tonnes in 2016. The share of exported wheat to total wheat production in Slovakia changed from $3.9 \%$ in 2002 to $48.1 \%$ in 2018 , with a maximum of $63.2 \%$ in 2017 . The share of imported wheat to total wheat production remained relatively low as Slovakia is self-sufficient in wheat - it was only $0.1 \%$ in 2002 and $1.2 \%$ in 2018. For wheat export and import, EU countries are the most important trade partners for Slovakia. The amount of wheat imported from and exported to EU countries increased from 58.6 th. tonnes in 2002 to 938.7 th. tonnes in 2018. The maximum trade volume with EU countries was recorded in 2016, i.e. 1,468.5 th. tonnes. Exports to the EU built up to $61 \%$ of Slovak wheat production (in 2017) and imports from the EU built up to $7.6 \%$ of Slovak wheat production (in 2011). 
Table 1: Share of wheat exports and imports to wheat production in Slovakia

\begin{tabular}{|c|c|c|c|c|c|c|c|c|c|c|}
\hline & & 2002 & 2003 & 2004 & 2005 & 2006 & 2007 & 2008 & 2009 & 2010 \\
\hline \multirow{2}{*}{$\begin{array}{l}\text { total } \\
\text { trade }\end{array}$} & $\mathrm{S}_{(\mathrm{EX}, \mathrm{t})}$ & $3.9 \%$ & $2.8 \%$ & $1.5 \%$ & $19.0 \%$ & $29.6 \%$ & $10.3 \%$ & $7.5 \%$ & $24.4 \%$ & $33.7 \%$ \\
\hline & $\mathrm{S}_{(\mathrm{IM}, \mathrm{t})}$ & $0.1 \%$ & $2.5 \%$ & $0.1 \%$ & $2.6 \%$ & $4.2 \%$ & $3.9 \%$ & $5.6 \%$ & $5.5 \%$ & $3.1 \%$ \\
\hline & & 2011 & 2012 & 2013 & 2014 & 2015 & 2016 & 2017 & 2018 & \\
\hline \multirow{2}{*}{$\begin{array}{l}\text { total } \\
\text { trade }\end{array}$} & $\mathrm{S}_{(\mathrm{EX}, \mathrm{t})}$ & $17.3 \%$ & $23.2 \%$ & $33.6 \%$ & $40.4 \%$ & $49.1 \%$ & $60.7 \%$ & $63.2 \%$ & $48.1 \%$ & \\
\hline & $\mathrm{S}_{(\mathrm{IM}, \mathrm{t})}$ & $7.6 \%$ & $6.7 \%$ & $1.3 \%$ & $1.9 \%$ & $2.4 \%$ & $0.6 \%$ & $1.4 \%$ & $1.2 \%$ & \\
\hline & & 2002 & 2003 & 2004 & 2005 & 2006 & 2007 & 2008 & 2009 & 2010 \\
\hline \multirow{2}{*}{$\begin{array}{l}\text { EU } \\
\text { trade }\end{array}$} & $\mathrm{S}_{(\mathrm{EX}, \mathrm{t})}$ & $3.7 \%$ & $2.7 \%$ & $1.2 \%$ & $6.3 \%$ & $16.6 \%$ & $9.8 \%$ & $7.3 \%$ & $24.3 \%$ & $33.7 \%$ \\
\hline & $\mathrm{S}_{(\mathrm{IM}, \mathrm{t})}$ & $0.1 \%$ & $2.5 \%$ & $0.1 \%$ & $2.6 \%$ & $4.2 \%$ & $3.9 \%$ & $5.6 \%$ & $5.5 \%$ & $2.9 \%$ \\
\hline & & 2011 & 2012 & 2013 & 2014 & 2015 & 2016 & 2017 & 2018 & \\
\hline \multirow{2}{*}{$\begin{array}{l}\text { EU } \\
\text { trade }\end{array}$} & $\mathrm{S}_{(\mathrm{EX}, \mathrm{t})}$ & $17.3 \%$ & $23.1 \%$ & $33.6 \%$ & $40.2 \%$ & $48.8 \%$ & $59.7 \%$ & $61.0 \%$ & $47.5 \%$ & \\
\hline & $\mathrm{S}_{(\mathrm{IM}, \mathrm{t})}$ & $7.6 \%$ & $6.7 \%$ & $1.3 \%$ & $1.9 \%$ & $2.4 \%$ & $0.6 \%$ & $1.4 \%$ & $1.2 \%$ & \\
\hline
\end{tabular}

Own calculations based on Eurostat data (2020).

The Slovak wheat market is interconnected with the European market mainly via wheat exports. The share of wheat exported to the EU to domestic wheat production has shown an increasing trend since Slovakia entered the EU (May 2004). In 2014, 2015 and 2018 more than 40\% of wheat harvested in Slovakia was exported to the EU, in 2016 and 2017 even more than 50\%. The figures show that the Slovak and European wheat markets are integrated and the EU is an important market for Slovak wheat producers.

\section{Wheat Prices}

The market price of wheat does not depend only on supply and demand for wheat in the Slovak market. Due to free trade within the EU and a common European market, wheat prices are affected by the situation in the whole EU, too. Total supply of wheat in the Slovak market consists of domestic production and imports, total demand for wheat consists of domestic consumption and foreign demand, i.e. exports (market balance of individual commodities is completed by usually negligible changes in stocks).

Slovak wheat prices and wheat prices in the EU over 2004-2018 suggest similarities in their development. European wheat prices are represented by French prices. France has been chosen as the representative of European prices because it is the biggest cereal producer in the EU and thus, it can influence EU wheat prices. In 2018, France produced more than a quarter of EU's wheat. Slovak and French prices are investigated as monthly price indices from May 2004 (when Slovakia joined the EU) to December 2018 for bread wheat with the average 2015 price representing the index 100 (in absolute terms, the average 2015 wheat price in Slovakia was EUR 154.8 per tonne and in France it was EUR 173.0 per tonne) (data source: EC, 2020). The highest wheat prices have been recorded in the Slovak and French market at the turn of 2007/2008, followed by a decline and another peak in 2011 and at the end of 2012. In 2014-2018, wheat prices did not change rapidly, there was only a 
slight decline followed by a slight growth. Prices at the end of the analysed period, in 2018, were almost at the level of prices ten years earlier. For wheat, producers' price of bread wheat reached EUR 155.75 per tonne, producers' price of industrial wheat was lower, EUR 140.44 per tonne in 2018 (NPPC, 2019).

Graph 3: Slovak and European (French) wheat prices

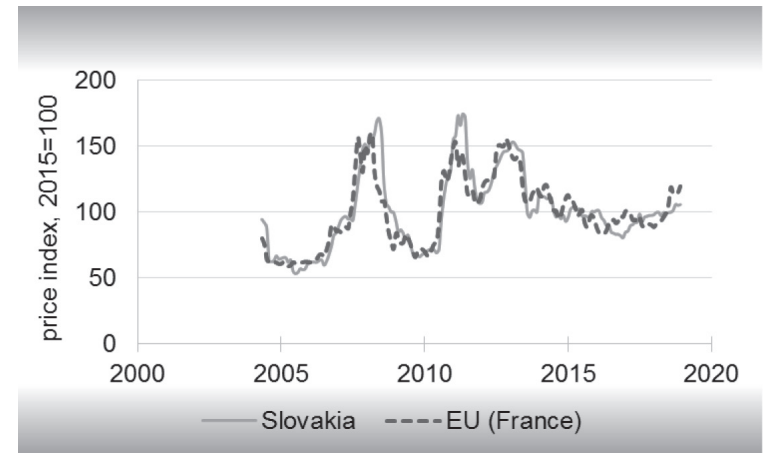

Data source: EC (2020).

Similar development of wheat prices in Slovakia and in the representative EU market, France, indicates the integration of the Slovak and European wheat market. Cointegration of both markets had been confirmed through statistical tests.

Time series of Slovak and European (bread) wheat price indices are not stationary (European prices are represented by French prices). However, the series in first differences are stationary, hence, both price indices series are stationary of degree 1. Tests for the stationary series in first differences are provided in Table 2.

The relationship between Slovak and European (French) wheat prices can be described by the estimated cointegration regression (see Table 3) as:

$$
\mathrm{P}_{(\mathrm{SK}, \mathrm{t})}=3.06+0.98 \mathrm{P}_{(\mathrm{EU}, \mathrm{t})}+\varepsilon_{\mathrm{t}}
$$

Dickey-Fuller test for residues and CRDW test confirmed the cointegration of the Slovak and European markets for wheat; results are given in Table 4. This means that wheat prices in France and in Slovakia move in a similar pattern and a long-run relationship between European (French) and Slovak wheat prices exists.

Table 2: Stationarity tests for Slovak and European wheat prices

A) Time series of Slovak wheat price indices (wheat_SK):

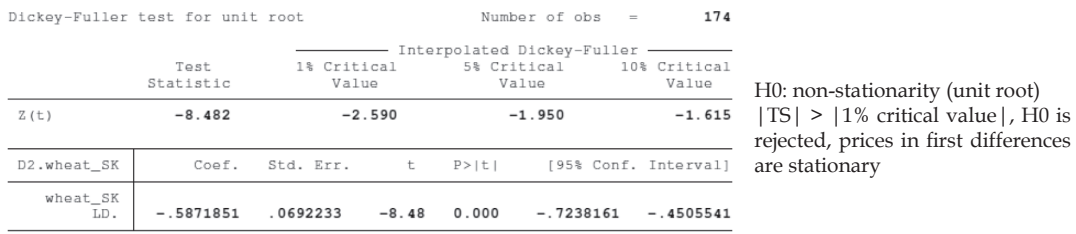


H0: stationarity

$|\mathrm{TS}|<\mid 1 \%$ critical value $\mid$ for all lags, $\mathrm{H} 0$ is not rejected, prices in first differences are stationary

B) Time series of European wheat price indices represented by French price indices (wheat_FR):

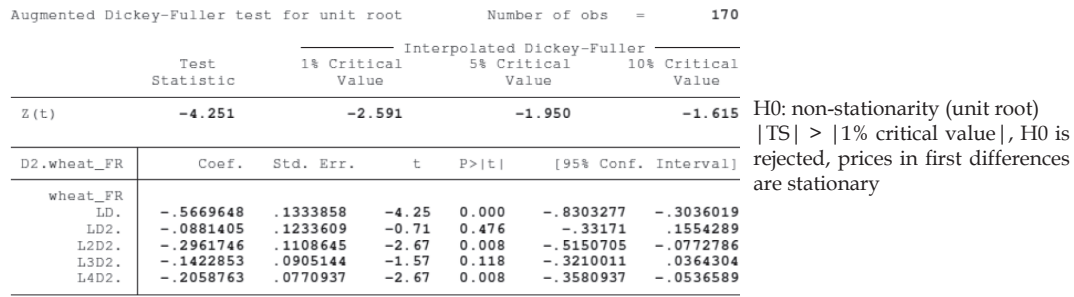

KPSS test for D.wheat_FR

Maxlag = 13 chosen by Schwert criterion

Autocovariances weighted by Bartlett kernel

Critical values for HO: D.wheat_FR is level stationary

H0: stationarity

$10 \%: 0.347 \quad 5 \%: 0.463 \quad 2.5 \%: 0.574 \quad 1 \%: 0.739$

$|\mathrm{TS}|<\mid 1 \%$ critical value $\mid$ for all

Lag order Test statistic lags, $\mathrm{H} 0$ is not rejected, prices in first differences are stationary

$\begin{array}{ll}0 & .07 \\ 1 & .0543 \\ 2 & .0518 \\ 3 & .0498 \\ 4 & .0478 \\ 5 & .0447 \\ 6 & .0421 \\ 7 & .0411\end{array}$

Own calculations based on Eurostat data (2020).

Table 3: Cointegration regression for Slovak and European wheat prices Regression for $\mathrm{P}_{(\mathrm{SK}, \mathrm{t})}=\mathrm{f}\left(\mathrm{P}_{(\mathrm{EU}, \mathrm{t})}\right)$

\begin{tabular}{r|rrr}
\hline Source & SS & df & MS \\
\hline Model & 118575.729 & 1 & 118575.729 \\
Residual & 32119.5133 & 174 & 184.594904 \\
\hline Total & 150695.242 & 175 & 861.115668
\end{tabular}

$\begin{array}{lrr}\text { Number of obs } & =176 \\ \text { F( 1, 174) } & =642.36 \\ \text { Prob }>\text { F } & 0.0000 \\ \text { R-squared } & 0.7869 \\ \text { Adj R-squared } & =0.7856 \\ \text { Root MSE } & =13.587\end{array}$

\begin{tabular}{|c|c|c|c|c|c|c|c|}
\hline wheat_SK & Coef. & Std. Err. & $\mathrm{t}$ & $P>|t|$ & {$\left[95 \frac{8}{8}\right.$} & Conf. & Interval] \\
\hline $\begin{array}{r}\text { wheat_FR } \\
\text { _cons }\end{array}$ & $\begin{array}{r}.979142 \\
3.060256\end{array}$ & $\begin{array}{l}.0386329 \\
3.995275\end{array}$ & $\begin{array}{r}25.34 \\
0.77\end{array}$ & $\begin{array}{l}0.000 \\
0.445\end{array}$ & $\begin{array}{r}.9028 \\
-4.825\end{array}$ & $\begin{array}{l}8925 \\
5184\end{array}$ & $\begin{array}{r}1.055391 \\
10.9457\end{array}$ \\
\hline
\end{tabular}

where wheat ${ }_{\mathrm{SK}}$ is Slovak wheat price $\left(\mathrm{PSK}, \mathrm{t}\right.$ ) and wheat $_{\mathrm{FR}}$ is European wheat price $(\mathrm{PEU}, \mathrm{t})$ represented by French wheat price.

Own calculations based on Eurostat data (2020). 
Table 4: Stationarity of residues from the cointegration regression Time series of residues from cointegration regression (wheat_res)

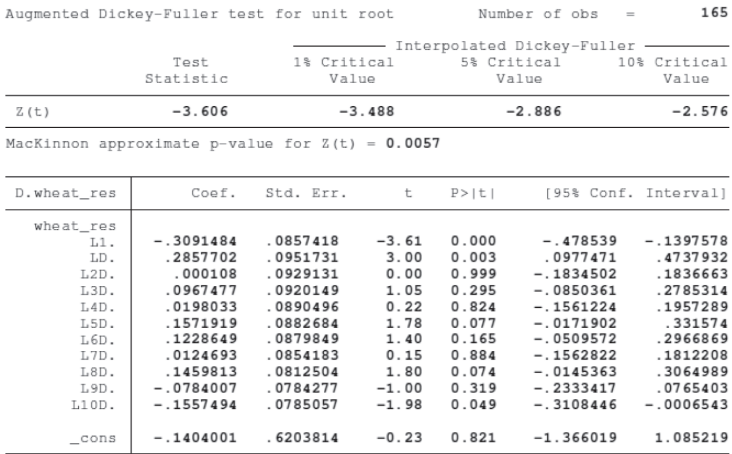

$5 \%$ critical value $=-3.34($ Verbeek, 2004)

Durbin-Watson d-statistic $(2, \quad 176)=\mathbf{4 2 4 6 9 6 9}$

$5 \%$ critical value for 100 observations $=0.38$,

$5 \%$ critical value for 200 observations $=0.20$ (Verbeek, 2004)

$\rightarrow 5 \%$ critical value for 176 observations $\approx 0.22$

Own calculations based on Eurostat data (2020).
H0: non-stationarity (unit root) $|\mathrm{TS}|>\mid 5 \%$ critical value $\mid, \mathrm{H} 0$ is rejected, residues are stationary

\section{Conclusion}

Cereals are a pillar of crop production in Slovakia (Jamborova, 2018). The most cultivated cereal is wheat. Slovakia is self-sufficient in wheat, hence the supply of wheat in the Slovak market consists mainly of domestic production, and imports of this commodity are minimal. In addition, Slovak wheat production is exported and serves to cover foreign demand. Since Slovakia's accession to the European Union, Slovak producers have used the opportunity to trade with crops in the markets of other EU Member States without any trade barriers.

Kaliska (2019) points out that the integration of the Slovak and European market is supported by intensive trade relations: she expects that more than a half of Slovak wheat should go for export in 2019. Moreover, she adds that overproduction of wheat in the EU, especially in France (which should reach the second highest wheat harvest in history in 2019), leads to a relatively low market price of wheat. Low wheat prices, despite of good domestic production, lead to unsatisfactory economic results of Slovak farmers. The finding of Jamborova (2018) confirms our results regarding market integration; the author states that the development of cereal prices in Slovakia is related to price volatility in the European and world market.

The integration of the Slovak and European market is an ongoing process facilitated by the existence of a single European market. The domestic and the EU wheat market are interconnected through international trade and a common movement of wheat prices. In general, a cointegration approach has been used to estimate the significance of European regional integration. Studies suggest a small but positive effect of EU integration on trade and that regional integration has a more beneficial effect on trade (Stack - Pentecost, 2011). In other studies in the case 
of EU, it has been found that the intra-union trade-creation effect is much larger than extra-union effects in contrast to other regional zones where either exports to third countries are significantly diverted or results indicate that the integration has not contributed to intra-union trade as well as in few cases the members are still significantly dependent on extra-union imports (Geldi, 2012). To design appropriate measures for Slovak wheat growers, we recommend to further study trade creation and trade diversion effects and also price relations and price transmission from the European to the national market (for price transmission see e. g. Moser et al., 2009). Wheat is of importance not only for Slovak farmers, it has a role in providing food for the population; therefore, wheat market should be a subject of interest for both researchers and policy makers.

\section{Acknowledgements}

This work was supported by the Slovak Research and Development Agency under the contract no. APVV-15-0552 and by the Scientific Grant Agency of the Ministry of Education, Science, Research and Sport of the Slovak Republic under the project no. VEGA 1/0422/19.

\section{Bibliography}

1. Abdulai, A. (2000). Spatial Price Transmission and Asymmetry in the Ghanaian Maize Market. Journal of Development Economics, 63 (2), 2000. pp. 327-349. DOI: 10.1016/S0304-3878(00)00115-2.

2. Amikuzuno, J. et al. (2013). Price Transmission between Imported and Local Rice Markets in a Liberalised Economy: Are Ghana's Rice Wars Just Much I Do About Nothing? Journal of Economics and Sustainable Development, 4 (20), 2013. pp. 109-119.

3. Awika, J. M. (2011). Major Cereal Grains Production and Use around the World. In: Awika, J. M. et al.: Advances in Cereal Science: Implications to Food Processing and Health Promotion. Washington: American Chemical Society; ACS Symposium Series, 2011. 13 pp. [Online https:/ / pubs.acs.org/doi/pdf/10.1021/bk-2011-1089. ch001, accessed 05.10.2020].

4. Braha, K. et al. (2017). Determinants of Albanian Agricultural Export: The Gravity Model Approach. AGRIS on-line Papers in Economics and Informatics, 9 (2), 2017. pp. 3-21. DOI: 10.7160/aol.2017.090201.

5. EC (European Commission). (2014). EU-10 and the CAP: 10 Years of Success. [Online https://ec.europa.eu/info/sites/info/files/food-farming-fisheries/ farming/documents/agri-policy-perspectives-eu10-and-cap_2014_en.pdf, accessed 01.09.2020].

6. EC (European Commission). (2019). EU Cereal Farms Report based on 2017 FADN Data. [Online https://ec.europa.eu/info/sites/info/files/food-farmingfisheries/farming/documents/ fadn-cereal-report-2017_en.pdf, accessed 01.09.2020].

7. EC (European Commission). (2020). The Common Agricultural Policy at a Glance. [Online https:/ / ec.europa.eu/info/food-farming-fisheries/key-policies/ common-agricultural-policy/cap-glance, accessed 01.09.2020].

8. EC (European Commission). EU prices for selected representative products. [Online https://ec.europa.eu/info/food-farming-fisheries/farming/ facts-and-figures/markets/prices/price-monitoring-sector/eu-prices-selectedrepresentative-products_en, accessed 01.09.2020]. 
9. EUROSTAT. Data - Database by themes. [Online https://ec.europa.eu/eurostat/ data/database, accessed 01.09.2020].

10. FAO (Food and Agriculture Organization of the United Nations). (2003). World Agriculture: towards 2015/2030. An FAO Perspective. Earthscan Publications, 2003. 432 pp. ISBN 92-5-104835-5. FAO (Food and Agriculture Organization of the United Nations). (2018). The Future of Food and Agriculture - Alternative Pathways to 2050. Rome: FAO, 2018. 224 pp. ISBN 978-92-5-130158-6.

11. Geldi, H. K. (2012). Trade Effects of Regional Integration: A Panel Cointegration Analysis. Economic Modelling, 29 (5), 2012. pp. 1566-1570. DOI: 10.1016/j. econmod.2012.05.017.

12. Granger, C. W. J., \& Newbold, P. (1974). Spurious Regressions in Econometrics. In: Journal of Econometrics, 2 (2), 1974. pp. 111-120. DOI: 10.1016/03044076(74)90034-7.

13. Jamborova, M. (2018). Situácia na trhu obilnín a olejnín. Situácia a perspektívy trhu vybraných agropotravinárskych komodít v SR. International scientific conference, Senec, 22.3.2018. [Online http://www.nppc.sk/index.php/sk/home/2-all/400vuepp-polnohospodarsko-ekonomicka-konferencia-2018, accessed 05.10.2020].

14. Listorti, G., \& Esposti, R. (2012). Horizontal Price Transmission in Agricultural Markets: Fundamental Concepts and Open Empirical Issues. Bio-based and Applied Economics, 1 (1), 2012. pp 81-108. DOI: 10.13128/BAE-10769.

15. Kaliska, I. (2019). Rok 2019 priniesol priemernú úrodu obilnín. Sladovníci budú musiet' jačmeň dovážat'. Polnoinfo.sk, 22.9.2019. [Online https://polnoinfo.sk/ rok-2019-priniesol-priemernu-urodu-obilnin-sladovnici-musia-velke-objemyjacmena-dovazat/, accessed 05.10.2020].

16. Matoskova, D. et al. (2015). Situácia v sektore obilnín s akcentom na ich využitie v mlynskom priemysle. Ekonomika pol'nohospodárstva, 15, 2, 2015. 18 pp.

17. Moser, C. et al. (2009). Spatial Integration at Multiple Scales: Rice Markets in Madagascar. Agricultural Economics, 40, 2009. pp. 281-294. DOI: 10.1111/j.15740862.2009.00380.x.

18. NPPC (Národné pol'nohospodárske a potravinárske centrum - National Agricultural and Food Centre). (2019). Situačná a výhl'adová správa k 31.12.2018 Obilniny. Bratislava: NPPC-VUEPP, 2019. 57 s. ISSN 1338-483X.

19. NPPC-VUEPP (National Agricultural and Food Centre - Research Institute of Agriculture and Food Economics). Situačné a výhl'adové správy - Obilniny for years 2004-2019. [Online http://www.vuepp.sk/04_komodity.htm, accessed 01.09.2020]

20. Shewry, P. R. et al. (2013). Natural Variation in Grain Composition of Wheat and Related Cereals. Journal of Agricultural and Food Chemistry, 61 (35), 2013. pp. 8295-8303. DOI: 10.1021/jf3054092.

21. Shewry, P. R., \& Hey, S. J. (2015). The Contribution of Wheat to Human Diet and Health. Food and Energy Security, 4 (3), 2015. pp. 178-202. DOI: 10.1002/fes3.64.

22. Stack, M. M., \& Pentecost, E. J. (2011). Regional Integration and Trade: A Panel Cointegration Approach to Estimating the Gravity Model. The Journal of International Trade and Economic Development, 20 (1), 2011. pp. 53-65. DOI: 10.1080/09638199.2011.538184.

23. SO SR (Statistical Office of the Slovak Republic). Database Datacubes. [Online https://slovak.statistics.sk/, accessed 01.09.2020].

24. Tangermann, S., \& von Cramon-Taubadel, S. (2013). Agricultural Policy in the European Union: An Overview. University of Goettingen, Department for Agricultural Economics and Rural Development, Working Paper No. 1302, 2013. 71 pp. [Online https://www.econstor.eu/bitstream/10419/70909/1/738371890. pdf, accessed 05.10.2020]. 
25. Tangermann, S. (2011). Policy Solutions to Agricultural Market Volatility: A Synthesis. International Centre for Trade and Sustainable Development, Issue Paper No. 33, 2011. 103 pp. [Online https://www.files.ethz.ch/isn/138403/ tangermann-price-volatility-and-policy-options.pdf, accessed 05.10.2020].

26. Van Huylenbroeck, G. et al. (2007). Multifunctionality of Agriculture: A Review of Definitions, Evidence and Instruments. Living Reviews in Landscape Research, 1 (3), 2007. 43 pp. DOI: 10.12942/lrlr-2007-3.

27. Verbeek, M. (2004). A Guide to Modern Econometrics. Chichester: Wiley, 2004. 429 pp. ISBN 0-470-85773-0.

\section{Correspondence address:}

doc. Ing. Artan Qineti, PhD., Department of Economic Policy, Faculty of Economics and Management, Slovak University of Agriculture in Nitra, Trieda A. Hlinku 2, 94976 Nitra, Slovakia, email artan.qineti@uniag.sk

Ing. Ema Lazorčáková, PhD., Department of Economic Policy, Faculty of Economics and Management, Slovak University of Agriculture in Nitra, Trieda A. Hlinku 2, 94976 Nitra, Slovakia, email ema.lazorcakova@uniag.sk 